20. Podvodnye lodki. MIL.PRESS FLOT. URL: https://flot.com/nowadays/strength/ submarines, 1 (in Russian).

Матеріал надійшов до редакиії 06.01.2021 p.

УДК 911.3:338.48(620)(091)

\title{
Галина Копачинська,
}

кандидат географічних наук,

доцент кафедри міжнародних відносин і регіональних студій,

Волинський національний університет імені Лесі Українки,

ORCID ID 0000-0002-9395-8730

kopachinskaja@gmail.com

\section{Ірина Мандрик,}

кандидат географічних наук,

доцент кафедри економічної та соціальної географії,

Волинський національний університет імені Лесі Українки,

ORCID ID 0000-0001-9760-0130

mandryk2008@gmail.com

\section{Іван Сугак,}

студент 5 курсу освітньо-професійної програми «Регіональні студії», Волинський національний університет імені Лесі Українки, sugakvana@gmail.com

DOI 10.29038/2524-2679-2021-01-220-239

\section{ІСТОРИЧНІ ЕТАПИ РОЗВИТКУ ТУРИЗМУ В ЄГИПТІ}

У статті розглянуто Єгипет як одну з провідних туристичних дистаниій сучасного світу. Обтрунтовано необхідність дослідження та аналізу основних етапів становлення туризму в Сгипті. Розкрито характерні риси державотворення Єгипту. Доведено, яким чином історія становлення державності в Сгипті впливала на особливості зародження та еволюиї туризму в ньому. Вивчено основні праці вітчизняних $і$ зарубіжних науковиів щодо аналізу розвитку туризму та становлення туристичної галузі в державі. Розглянуто наукові методи, застосування котрих дає змогу комплексно вивчити й проаналізувати історичні етапи становлення туризму в державі. На основі отриманих результатів дослідження в статті запропоновано виокремлення трьох

(C) Копачинська Г., Мандрик I., Сугак I., 2021 
основних етапи історичного розвитку туризму в Сгипті, а саме: 1) початкового (IV cm. до н. е. - початок XX cm.), щуо характеризується появою перших подорожей до Сгипту та з нього на основі торгових, пізнавальних, освітніх і військових мотивів, нарощенням культурно-пізнавального потенціалу держави, будівництвом усесвітньо відомих культурноісторичних пам'яток; 2) зародження та еволюиї організованого туризму (поч. XX ст. - кінец̧ь XX сm.), щзо характеризується організацією перших туристичних подорожей, а також їх активізацією, закладанням основ для розвитку туристичної індустрї̈, появою масового туризму, нарощенням туристського потенціалу держави; 3) сучасного (поч. XXI cm. дотепер), шуо характеризується активним розвитком Сгипту як одного 3 найвідоміших туристичних центрів Африканського туристичного регіону. У статті розкрито основні характеристики кожного $з$ досліджуваних етапів. Обгрунтовано доиільність їх виділення в таких часових рамках, які представлено в статті. Проаналізовано основні види подорожей до Сгипту та з нього до початку XXI cm., а також основні види туризму, які представлено в державі на сучасному етапі. У cmami вивчено політико-правові, соціально-економічні та культурні чинники розвитку туризму в державі на кожному з запропонованих історичних етапів. Розглянуто основні характеристики розвитку туризму в Сгипті на сучасному етапі й обтрунтовано основні перспективи подальших досліджених з обраної наукової тематики.

Ключові слова: туризм, історичний етап, Єгипет, історико-культурна пам'ятка, розвиток, подорож.

\section{1. ВСТУП}

Постановка проблеми. Арабська Республіка Єгипет - північноафриканська близькосхідна країна, що входить до Африканського туристичного регіону й займає досить вигідне геотуристичне положення, адже розміщена в безпосередній близькості до одного 3 найбільших споживчих туристичних ринків - Європи - та має вихід до узбережжя Середземного й Червоного морів. Держава є осередком давньої цивілізаціï, а на їі території розташовані всесвітньо відомі атракції (піраміди Гізи, долина царів у Луксорі, гора Мойсея, монастир святої Катерини), а також музеї із безцінними колекціями історичного та культурного значення. Туризм Сгипту відіграє надзвичайно важливу економічну роль, адже є одним із найбільших джерел доходів до бюджету країни. Незважаючи на низку негативних політичних чинників, таких як постійні терористичні атаки й напади на іноземців у країні, нестабільну політичну ситуацію в межах кордонів держави, а також сусідство з осередком міжнародної 
напруги, у центрі котрого розміщені сектор Газа, Ізраїль і Палестина, туризм у державі розвивається досить активними темпами. Свідчення цього - той факт, що станом на 2019 р. Єгипет став однією з найбільш відвідуваних країн Африки поряд із Марокко та Південною Африкою; близько $10 \%$ зайнятих країни працює саме у сфері туризму $(2,5$ млн осіб); дохід від туризму у ВВП держави становить близько 29,6 млрд дол. США, або 6 \% від загального обсягу виробництва. Проте розвивався туризм у державі не завжди однаково, та й досить тривалий час Сгипет не мав власно сформованої державності, перебуваючи під владою різних країн чи імперій. Незважаючи на всі ці чинники й виклики сучасності, такі як поширення пандемії коронавірусної хвороби, держава намагається використовувати різноманітні методи й важелі впливу та сприяти нарощенню туристичного потенціалу Сгипту й збільшувати показники туристичних прибуттів. Для того щоб зрозуміти особливості зародження та еволюції туризму в Єгипті, вивчити шлях подолання труднощів щодо його розвитку, а також перейняти позитивний досвід для розвитку туристичної галузі в Україні, важливим й актуальним завданням сьогодення вбачаємо вивчення, виділення та обгрунтування історичних етапів розвитку туризму в Сгипті, що й зумовило вибір теми цього наукового дослідження.

Аналіз останніх досліджень і публікацій. Першочерговим завданням під час написання цієї наукової статті було опрацювання наукових джерел 3 історії розвитку та формування державності в Єгипті, адже цей процес прямо вплинув і на історію розвитку туризму в державі. Для виконання цього завдання проаналізовано підручник «Історія держави і права зарубіжних країн» за загальною редакцією М. О. Бандурки [1], а також низку наукових праць, де вивчалося питання історії розвитку міжнародного туризму, із частковим вивченням питання розвитку туризму в Сгипті, серед котрих - праці таких авторів, як В. В Абрамов, М. В. Тонкошкур [2], В. С. Великочий, О. І. Дутчак, В. В. Шикеринець [3], Ю. С. Путрик, В. С. Багдасарян, М. Б. Биржаков [4], М. В. Соколова [5], Мартін Андерсон [6], Мохамед Нейм [7] й ін.

Аби обгрунтувати, чому туризм у Сгипті бере свій початок із XXI ст., а до того часу з країни та до країни відбувалися саме подорожі за різним призначенням, у статті використано наукові праці з теорії міжнародного туризму, у яких охарактеризовано основні ознаки туризму і його відмінність від подорожей, із яких він й еволюціонував. Для цього опрацьовано праці таких авторів, як Т. Божидарник [8], М. П. Мальська, В. В. Худо, В. І. Цибух. [9] та ін. 
Попри те, що Сгипет є одним із провідних центрів сучасного туризму, вивченню особливостей його розвитку тут приділено недостатню увагу, адже досить незначною $є$ кількість комплексних наукових праць із цієї тематики. Особливо мало досліджень щодо історії розвитку туризму в державі. Так, серед тих вітчизняних науковців, хто досліджував певні аспекти розвитку туризму в СГипті, у тому числі й історію його зародження та розвитку, можна назвати Л. П. Воронкову $[10 ; 11]$, Л. М. Устименко, І. Ю. Афанасьєва [13] й ін.

Туристично-рекреаційні ресурси Єгипту, аналіз яких був необхідний для характеристики кожного із запропонованих у статті історичних етапів розвитку туризму в Сгипті, вивчали такі вчені, як Ю. Д. Дмитрієвський [14], М. П. Мальська [15], П. О. Масляк [16], В. І. Терещенко, Л. О. Штанько, В. П. Чаплигін [17].

Особливості розвитку туризму на сучасному етапі проаналізовано в працях Амна Пурі-Мірза [18], Лейли Вігналь [19], а також у статистичних інформаційних джерелах на сайті Всесвітньої туристичної організації [20] та інших інтернет-ресурсах.

Отже, аналіз вищезазначених первинних, вторинних i третинних літературних джерел дав підставу комплексно вивчити й виокремити історичні етапи розвитку туризму в Сгипті та охарактеризувати їхні головні ознаки.

Мета статті - комплексне вивчення й обгрунтування основних історичних етапів розвитку туризму в Сгипті на основі аналізу специфічних рис державотворення в Сгипті; зародження та еволюції перших подорожей; появи й еволюції організованого туризму в державі; становлення й розвитку туристичної індустрії в ній.

Методика дослідження. Комплексне вивчення історичних етапів розвитку туризму в Сгипті потребує застосування відповідних наукових методів, серед яких такі, як літературний, історичний, хронологічний, дихронний (метод періодизації), системний підхід, івент- та контент-аналіз. Першочергове значення для виконання наукового дослідження мало використання літературного методу, що полягає у вивченні різноманітних джерел інформації, які стосуються проблеми дослідження. Завдяки аналізу первинних, вторинних і третинних джерел інформації вдалося виконати грунтовне наукове дослідження особливостей формування основних історичних етапів розвитку туризму в Сгипті та їхніх головних характеристик.

У статті також застосовано історичний метод, який дав змогу провести ретроспективний аналіз і встановити причинно-наслідкові 
зв'язки, пов'язані з особливостями формування та еволюції історичних етапів розвитку туризму в державі. 3 історичним методом пізнання тісно пов'язаний хронологічний, використання котрого сприяло вивченню еволюції перших подорожей із держави та до неї, зародження й розвитку організованого туризму в Сгипті, уможливило розгляд історії формування державності в Сгипті та представлення іiі в хронологічній послідовності. Для виділення історичних етапів розвитку туризму в державі та обгрунтування їх доцільності використано дихронний метод.

У процесі написання статті застосовано також системний підхід, що передбачає дослідження зародження та еволюції туризму в державі як цілісного, системного явища. Застосування цього методу допомогло не лише вивчити особливості розвитку туризму в Сгипті на різних історичних етапах, але й проаналізувати його особливості на сучасному етапі з уврахуванням основних взаємопов'язаних передумов і чинників історичних, політико-правоих, соціально-економічних, культурних та ін.

Під час написання статті також застосовано контент- й івент-анліз. Контент-аналіз грунтується на вивченні офіційних інформаційних матеріалів, а івент-аналіз є методом вивчення публічної інформації на основі дослідження й систематизації подій у міжнародних відносинах. Використання цих методів дало змогу комплексно розглянути всі можливі чинники політичного, історичного, культурного та економічного характеру, що мали безпосередній вплив на історію розвитку туризму в Сгипті, що використано під час написання статті.

Отже, застосування таких наукових методів, як літературний, історичний, хронологічний, дихронний (метод періодизації), системний підхід, івент- та контент-аналіз, уможливило комплексне вивчення та виокремлення основних історичних етапів розвитку туризму в Сгипті й характеристику їхніх головних ознак.

\section{2. РЕЗУЛЬТАТИ ДОСЛІДЖЕННЯ}

Історія розвитку туризму в Сгипті безпосередньо пов'язана з історією становлення державності, адже Сгипет як незалежна держава, яка спроможна достатньою мірою розвивати власну індустрію туризму, з'явилася лише у ХХ ст.

Загалом, історію становлення державності в Єгипті прийнято поділяти на такі періоди: династичний - час правління фараонів (IV ст. до н. е. - 332 р. до н. е.), елліністичний (332 р. до н. е. - 30 р. до н. е.), римський (30 р. до н. е. - 395 р.), візантійський (395-640рр.), арабський 
(641-969 рр.), період тимчасової незалежності в епоху Середньовіччя (870-1517 рр.), турецький (1517-1914 рр.), британський (1914-1922 рр.) і новітній період із часу отримання незалежності від Великобританії в 1922 p. [1].

На основі аналізу історичних етапів становлення державності в Єгипті та вивчення особливостей розвитку туризму в країні пропонується класифікація історичних етапів розвитку туризму в державі, яка представлена в табл. 1.

Поява перших поселень на території сучасного Єгипту датується 7 тис. років тому, проте на той час умови для життя були значно кращими, ніж на сучасному етапі, оскільки в ті часи ще не було пустелі Сахари, а, замість неї, на території сучасного Сгипту була саванна. Перші ж поселення 3'явилися в долині річки Ніл, оскільки вона достатньо могла забезпечити водою й продуктами харчування i, як наслідок, саме на іiї території почало розвиватися землеробство. Ніл для єгиптян відігравав неабияку роль, адже він став ключовим засобом реалізації політичних, економічних соціальних і навіть релігійних цілей (саме по ньому перевозили кам'яні споруди для будівництва пірамід, плавали задля реалізації торгових

Таблиия 1

Основні історичні етапи розвитку туризму в Сгипті*

\begin{tabular}{|l|c|l|}
\hline $\begin{array}{c}\text { Назва } \\
\text { iсторичного } \\
\text { етапу }\end{array}$ & Часові рамки & \multicolumn{1}{|c|}{ Основні характерні ознаки } \\
\hline \multicolumn{1}{|c|}{$\mathbf{1}$} & $\mathbf{2}$ & \multicolumn{1}{|c|}{$\mathbf{3}$} \\
\hline $\begin{array}{l}\text { І історичний } \\
\text { початковий }-\end{array}$ & $\begin{array}{l}\text { IV ст. до н. е. }- \\
\text { початок XX ст. }\end{array}$ & $\begin{array}{l}\text { - Поява перших подорожей до } \\
\text { Сгпту та 3 нього на основі } \\
\text { торгових, пізнавальних, освіт- } \\
\text { ніх та військових мотивів і іх } \\
\text { активізація з плином часу; } \\
- \text { нарощення культурно-пізна- } \\
\text { вального потенціалу держави; } \\
- \text { оформлення й будівництво } \\
\text { культурно-історичних пам'яток } \\
\text { держави, що викликали інтерес } \\
\text { у потенційних туристів. }\end{array}$ \\
\hline
\end{tabular}

*Складено та розроблено авторами самостійно. 
Закінчення таблииі

\begin{tabular}{|c|c|c|}
\hline 1 & 2 & 3 \\
\hline $\begin{array}{l}\text { ІІ історичний } \\
\text { етап - } \\
\text { зародження } \\
\text { та еволюця } \\
\text { організованого } \\
\text { туризму }\end{array}$ & $\begin{array}{l}\text { початок XX ст. } \\
\text { - кінець XX ст. }\end{array}$ & $\begin{array}{l}\text { - Зародження туризму в пов- } \\
\text { ному значені цього поняття та } \\
\text { організація перших туристич- } \\
\text { них подорожей (на поч. ХХ ст. } \\
\text { Єгипет входив до складу Вели- } \\
\text { кобританії, на території котрої } \\
\text { в } 1841 \text { р. туризм і з'явився } \\
\text { внаслідок організації Томасом } \\
\text { Куком для членів товариства тве- } \\
\text { резості подорожі } 3 \text { Лейстера в } \\
\text { Лафборо); } \\
\text { - нарощення показників масо- } \\
\text { вого туризму; } \\
\text { - нарощення туристичного по- } \\
\text { тенціалу держави; } \\
\text { - закладанням основ та активний } \\
\text { розвиток туристичної індустрії. }\end{array}$ \\
\hline $\begin{array}{l}\text { III історичний } \\
\text { етап - } \\
\text { сучасний }\end{array}$ & $\begin{array}{l}\text { початок XXI ст. } \\
\text { - дотепер }\end{array}$ & $\begin{array}{l}\text { Попри негативні чинники } \\
\text { політичного характеру в межах } \\
\text { та поза межами держави, актив- } \\
\text { ний і динамічний розвиток Єгип- } \\
\text { ту як одного } 3 \text { найвідоміших } \\
\text { туристичних центрів Афри- } \\
\text { канського туристичного регіону. }\end{array}$ \\
\hline
\end{tabular}

*Складено та розроблено авторами самостійно.

цілей із країнами Тропічної Африки та Середземномор'я). Окрім того, єгиптяни були одними з перших, хто почав використовувати русла рік, що висохли, як дороги, i, як наслідок, могли реалізовувати свої торгові інтереси з багатьма регіонами й державами Африки, Середземномор'я та Близького Сходу.

I історичний етап розвитку туризму в Сгипті. Початок I-го історичного періоду розвитку туризму в Єгипті припадає на IV ст. до н. е., коли на території долини р. Ніл створюються перші великі держави, а саме «Верхній» і «Нижній» Сгипет, котрі внаслідок конфлікту між собою й перемогою «Верхнього» Сгипту в кінці IV ст. до н. е. об'єдналися в 
одну державу. Саме на цей час припадає початок династичного періоду в історії державотворення Єгипту. Наступні 1000 років Єгипет процвітав та активно розвивався, єгиптяни зуміли побудувати систему ірригації, активно розвивали свої ремесла, збільшували показники торгівлі із сусідніми народами, а також вели боротьбу з кочівниками. Потрібно відзначити, що протягом цього періоду розпочався також активний науковий пошук єгиптян, коли вони винайшли сонячний календар; збирали знання 3 геометрії, що дало змогу побудувати всесвітньо відомі піраміди (від першої 6-ступеневої піраміди Джосера до великих пірамід у Гізі); створювали надзвичайно гарну кераміку та золоті прикраси; розвинули власну політичну релігію; культ мертвих. Зароджується в цей період і стародавня єгипетська писемність, видозмінюються іiі ієрогліфи, з'являються перші писемні твори (т. зв. «тексти пірамід», що розповідали про життя після смерті та специфіку єгипетських ритуалів), а з III ст. до н. е., окрім появи папірусу, з'являються й перші школи [2].

Як наслідок, саме для цього періоду характерними стають торговельні та пізнавальні подорожі з Сгипту до сусідніх держав i iз сусідніх держав до нього. Активний розвиток Сгипту та його слава поза кордонами держави призвели до появи військових подорожей, що негативно позначилися на розвитку держави, адже неодноразово територію Сгипту намагалися захопити сусідні племена, наприклад племена гіксосів, котрим удалося навіть на початку 1500 р. до н. е. захопити всю територію Сгипту. У наступні роки, коли територію Сгипту вдалося звільнити від загарбників, розпочинається один із найкращих періодів розвитку держави (т. зв. «Нове царство»), адже саме під час нього територія Сгипту розширилася аж до Персії; єгиптяни освоїли мистецтво лиття бронзи; розпочали використовувати в боях колісниці; будували численну кількість нових храмів.

Найбільшу кількість подорожей до Сгипту протягом цього періоду здійснювали купці, особливо з Греції та Риму, оскільки їх приваблювали незвичайна природа, історія, культура та велич єгипетських споруд. Окрім того, вони залишали спогади про себе у вигляді невеличких зображень графіті.

Для розвитку подорожей велике значення мали міжкультурні контакти древніх цивілізацій, адже саме в цей час набула популярності традиція відвідувань країн Сходу грецькими філософами, де вони мали змогу вивчати східну культуру та використовувати свої спостереження для наукової діяльності. Поступово відбувалося збільшення знань про світ, а подорожі Сгиптом ставали важливим елементом накопичення 
інформації, підтвердження чого - праці «батька історії» Геродота (близько 484 р. до н. е. - близько 425 р. до н. е.), котрий залишив нащадкам велику кількість цікавих даних про життя єгиптян, описаних у дев'яти книгах, присвячених Сгипту [4]. Його по праву можна назвати першим відвідувачем-туристом із Греції, про якого збережені достовірні дані. Саме завдяки його працям можна робити висновки про те, що такі культурно-історичні пам'ятки Єгипту, як славетний єгипетський лабіринт, Фаюмський оазис, храми Ком-Омбо й Абу-Сімбел, піраміди та великий Сфінкс у стародавні часи захоплювали подорожувальників не менше ніж у наші дні. Після завоювання Сгипту Александром Македонським об'ємні географічні знання, зібрані в Єгипті, вивчені та використані на практиці давньогрецькими вченими.

Саме протягом цього історичного етапу Сгипет став освітнім центром, адже майже всі видатні стародавні філософи намагалися відвідати його та отримати знання, серед них - Арістотель (385/384322/321 рр. до н. е.), Демокріт (близько 470/460-60-е pp. IV ст. до н. е.), Квинтиліан (близько 35-100 pр. до н. е.), перший грецький філософ, математик й астороном Фалес Мілетський (640/624-548/545 pр. до н. е.), філософ і математик Піфагор (570-495 рр. до н. е.), Платон (428/427348/347 рр. до н. е.) й низка ін. [3].

Великої популярності в Сгипті набула наука, подорожі з Сгипту мали не лише торгово-економічний чи військовий характер, а й освітній. Фараони та царі організовували експедиції задля набуття географічних, етнографічних, біологічних знань, можна навіть припустити, що єгиптяни були вмілими картографами (як доказ - карта доріг золотовидобувних шахт на березі Червоного моря 1500 р. до н. е.), проте здебільшого їхні карти були символічними, такими як карта шляхів у потойбічний світ та ін.

До подорожей у Стародавньому Сгипті ставилися 3 особливою повагою, адже вважалося, що подорожувальника оберігають боги, саме тому перед початком подорожі відбувалося жертвоприношення. Коли ж були сформовані основні релігійні течії, то в Сгипті з'явилася нова категорія мандрівників-пілігримів, які здійснювали паломницькі подорожі по «Святих місцях».

Для багатьох держав Сгипет був місцем лікування різноманітних хвороб, що стало приводом зародження й розвитку подорожей із лікувально-оздоровчими цілями, адже медицина в Єгипті почала активно розвиватися ще в VI ст. до н. е., особливо ж популярними у країні було грязелікування. Сприяли розвитку подорожей і всі переваги єгипетської цивілізації: порівняно якісні й безпечні дороги, а також 
транспортні засоби, котрі були спроможні долати значні відстані як на суходолі, так і по воді. Сгиптяни були також першими, хто розпочав будівництво лікувальних закладів, які з часом ставали поєднаними в цілу «санаторну» мережу, що частково функціонує й дотепер.

Для реалізації торгових подорожей єгиптяни розвивали навігацію по р. Ніл, плавання по акваторіях Середземного та Червоного морів, а також розбудову караванних доріг (караванна дорога пролягала 3 центральної частини країни через Червоне море до сусідніх країн). Найбільшого ж розквіту мореплавство досягло в часи завоювання Єгипту греками. Найбільший порт в Александрії оснащений маяком висотою 200 м (о. Фарос) - уночі світло від вогнища, розведеного на маяку, розходилося на далекі відстані завдяки металічним дзеркалам, недаремно Фароський маяк вважається одним із семи чудес світу.

Потрібно відзначити, що єгиптяни не були вправними мореплавцями, по-перше, через особливості р. Ніл, яка була мілкою в дельті та не мала зручних гаваней, що не давало змогу здобути необхідні навики щодо керівництва суднами; по-друге, бідними були запаси будівельних матеріалів Єгипту. Саме тому для далеких плавань єгиптяни використовували кораблі, зведені в порту Бібл, що належав фінікійцям, а необхідні матеріали для будівництва суден купували в Сирії та Лівані (наприклад деревина сосни чи кедру). Як наслідок, єгиптянам удалось активізувати торгівлю морем й отримувати золото, слонову кістку, вироби з камею та фаянсу, що привозились із сусідніх країн.

Iз 1080 р. до н. е. на території Єгипту настав період хаосу, адже держава розпалася на численну кількість маленьких держав, владу постійно ділили між собою то одні, то інші правлячі династії. Окрім того, більша частина території відійшла під владу Персії. Із 332 р. до н. е. 3 приходом до влади Александра Македонського розпочинається елліністичний період історії Сгипту, під час якого єгипетська культура зазнала великого впливу грецької. Столицю країни перенесено до Александрії Сгипетської на узбережжі Середземного моря. Після смерті Александра Македонського влада над Сгиптом перейшла до Птолемея, династія котрого правила Сгиптом до приходу римлян [10].

Саме в цей елліністичний період єгипетська культура повністю злилася 3 грецькою, офіційною мовою стала грецька, вся офіційна переписка велася теж грецькою мовою, закони того часу були поєднанням грецьких та єгипетських. Проте, саме в цей період на території Сгипту з'явилася всесвітньо відома Александрійська бібліотека, найпотужніша в Стародавньому Світі; розвивалися різні напрями науки; 
була запропонована перша система будови космосу жрецем Манефеном; написана перша історична праця про класифікацію історії Сгипту.

У 30 р. до н. е. Єгипет перейшов під владу Римської імперії, а з 395 р. н. е. до Візантійської імперії, у складі якої пробув до 642 р. На цей час Сгипет утратив свій статус «центру цивілізації», хоча статус «центру науки» так і лишався за Александрією. У цей період переважали освітні подорожі до Єгипту.

Близько 640 p. н. е. Сгипет захоплено військами арабського халіфату, що стало однією з ключових подій у розвитку держави, адже саме араби принесли в державу іслам і за наступні століття перетворили населення Сгипту в повністю арабське з культурного погляду. Християнські мешканці Єгипту (копти) поступово асимілювалися 3 арабським населенням у культурному та релігійному плані. Окрім того, саме в цей період унаслідок численних пожеж повністю зруйнованоу Александрійську бібліотеку та Александрія поступово почала втрачати свій статус «освітнього центру». Близько 870 р. н. е. вже мусульманський Єгипет вийшов з Арабського халіфату і став незалежним. До 1517 р. ним правили різі династії, проте одним із найвідоміших правителів був Саладін (Салах ад-Дін), відомий своїми перемогами над хрестоносцями [22].

У 1517 р. Єгипет перейшов під владу турків-османів і став частиною Османської імперії. Саме протягом цього періоду Сгипет зазнав свого найбільшого розквіту. Відомою подією цього етапу можна назвати завойовницький похід Наполеона 1798-1801 рр., метою якого був перерозподіл сфер впливу в Азії. Окрім того, саме в цей період, у 1799 р., віднайдено відомий широкому колу туристів «розетський камінь», що вважається однією 3 найвагоміших знахідок в історії Єгипту, адже саме на ньому один і той самий текст написаний трьома мовами - давньоєгипетською, демотичною (варіант давнього письма) і давньогрецькою. Оскільки давньогрецька мова була зрозуміла вченим, їм удалося розшифрувати ті ієрогліфи, які було неможливо розшифрувати раніше [8].

Зароджується в цей час нова наука під назвою «єгиптологія», основне завдання якої - вивчення Стародавнього Сгипту, що зумовило збільшення кількості вчених, які приїздили на територію Сгипту з Свропи.

Проте найбільш популярними на цььму етапі стали паломницькі подорожі до Сгипту, активізація яких розпочалася ще з часів Середньовіччя, адже саме на території держави змогли врятувати життя Ісусу Христу Марія та Йосиф після наказу Ірода вбивати всіх новонароджених дітей. 
Сгипет із давніх часів був відомий як країна, де відбувалося багато подій із Біблії, саме тому паломники досить часто подорожували до Нижнього Єгипту та Синаю. Приваблював Єгипет і паломників-мусульман, які подорожували до Верхнього Сгипту та Нубії, а далі - до аравійського міста Мекки, як того вимагав Коран. Подорожі паломників були важкі та досить виснажливі, адже подорожували вони пішки або на верблюдах, що описано в працях єгипетського історика Абдуррахмана аль-Джабарті (1754-1826). I хоча святі міста мусульман-паломників Мекка та Медина розміщені в Хіджазі, на території сучасної Саудівської Аравії, Сгипет відігравав важливе значення на шляху до них. Окрім того, на території Єгипту є велика кількість місць поховань так званих «місцевих святих», котрих називають сеїдами, котрі під час благословення могли вилікувати від будь-яких захворювань. Культ святих набув великого поширення в Єгипті та процвітає й досі. Так, великою популярністю стали користуватися місця поховання святого Ахмад аль-Бадаві в місті Танта (Нижній Сгипет); могила святого Абуль-Хасана Алі ібн Абдуллаха аш-Шазилі в Хумайсирі (Верхній Сгипет); у Каїрі - могила Марзука аль-Ахмаді [14].

Не меншою популярністю в Сгипті стали користуватися православні монастирі, кількість яких надзвичайно велика, особливо на територіях, заселених коптами. Православні паломники відвідували гору Мойсея висотою у 2285 м, яку з III ст. активно почали заселяти монахи (біблійна гора Хорив - так звана «гора 10 заповідей», які вручено Мойсею на ній); печеру пророка Іллі, у якій він ховався від гніву цариці Ієзавели та гору святої Катерини висотою в 2642 м, на якій у VI ст., за наказом імператора Юстиніана, зведено монастир, у котрому й дотепер зберігаються мощі Святої [17].

У 1798-1800 pр. Сгипет окуповано Французькими військами, після відступу яких у країні розпочалася громадянська війна. Переміг у цій війні Мухаммед Алі (1769-1849), який за підтримки єгиптян домігся призначення себе османським намісником. Визнавши зверхність султана, Муххамед Алі намагався перетворити Сгипет на могутню державу. Держава відібрала на свою користь більшість орних земель і змушувала селян вирощувати різноманітні культури, у тому числі й бавовну, із метою продавати їх закордон. Уряд контролював усю зовнішню торгівлю. Свропейці прагнули отримати право безмитної торгівлі в Сгипті таке ж, яке вони мали в інших частинах Османської імперії і, зрештою, у 1841 р. вони досягли своєї цілі [13].

У цей період Сгипет стає осередком арабського національного відродження («Нахда», що з арабської означає пробудження), у Каїрі 
засновано державну школу іноземних мов, започатковано першу арабську газету. Розпочато археологічні дослідження пам'яток стародавніх цивілізацій Близького Сходу.

За підтримки європейського капіталу (найбільшу частку якого становив французький) у 1859-1869 рр. французом Фердинардом де Лессепом збудовано Суецький канал. У 1875 р. значну частку акцій товариства Суецького каналу викупила Велика Британія, яка у 1882 р. розпочала окупацію Сгипту. Підписана в 1888 р. міжнародна конвенція про Суецький канал закріпила правовий статус британських військових сил у його зоні [5].

II історичний етап розвитку туризму в Сгипті. У 1914 р. Сгипет перейшов у повну владу Великобританії. У 1922 р. у результаті національно-визвольного руху проголошена незалежність Сгипту на чолі з королем Фуадом I, котрого позбавлено влади в 1953 р., унаслідок чого Сгипет став республікою на чолі з Президентом Моххамедом Насером.

Період із часу отримання незалежності державою є досить насиченим на різні події, у тому числі кровопролитні (війни з Ізраїлем, поділ влади) і не є легким, адже велику увагу до Сгипту привертає той факт, що саме тут розміщений Суецький канал, одна з найважливіших транспортних артерій Європи, найбільш завантажений міжнародний морський судноплавний коридор у світі, оскільки він з'єднує Середземне й Червоне моря, дає змогу сполучення між Свропою та Азією максимально коротким шляхом. Зважаючи на високе транспортне значення Суецького каналу, у 1956 р. Сгипет його націоналізував [22].

У 1958 р. Сгипет об'єднався із Сирією, створивши Об'єднану Арабську Республіку, із якої Сирія вийшла в 1961 р. У 1971 р. країна трансформувалася в Арабську Республіку Сгипет на чолі з президентом Хосні Мубараком.

Протягом цього історичного етапу відбулося не лише зародження туризму в повному значенні цього поняття, але і його активний розвиток у державі. Для сприяння збільшенню туристичних потоків у державу в 1957 р. зменшено візові обмеження майже для всіх країн Свропи та Америки, відкрито низку посольств у нових країнах, таких як Австрія, Нідерланди, Фінляндія та інших. У 1957 р. урядом прийнято п’ятирічний план розвитку держави, де одним із важливих пунктів був розвиток туризму, унаслідок чого 12 \% бюджету виділено на модернізацію державних готелів, сприяння з боку держави до будівництва приватних готелів, покращення туристичної інфраструктури. Окрім того, залучившись допомогою 
експертів із Туреччини, в 1979 р., у Сгипті було відкрито кілька нових навчальних закладів, у яких почали викладатися навчальні курси 3 управління туризмом і питань гостинності [12].

Кількість туристичних відвідувань Сгипту почала зростати з кожним роком значними темпами.

III історичний етап розвитку туризму в Сгипті. Із початку XXI ст. на нарощення туристичного потенціалу держави значний негативний вплив мали загрози політичного характеру, оскільки вони підривають туристичний авторитет Сгипту. Так, ще в кінці 90-х рp. ХХ ст. в розправі в Луксорі вбито 58 іноземних туристів; у 2004 р. відбулися вибухи в Синаї; у 2005 р. - теракти в Каїрі; у липні 2005 р. - вибухи в Шарм-ель-Шейху; у 2006 р. - вибухи в Дахабі - ці всі події стали наслідком дій бойовиків, що намагалися протидіяти уряду Мубарака й нападали на іноземців, котрі не $\epsilon$ мусульманами. Окрім того, на початку 2011 р. в Єгипті відбулися громадські повстання проти влади президента та, як наслідок, 11 лютого 2011 р. владу передано до Вищої ради збройних сил, а з 2016 р. президентом Сгипту став Абдул-Фаттах Халіл Ас-Сici (1954 р. н.) [23].

Під час Сгипетської революції 2011 р. відбулися напади на іноземних журналістів, а у 2012-2013 pp. - ще низка протестів із завданням тілесних ушкоджень іноземним відпочивальникам. Усі ці події призвели до того, що кількість туристів у Сгипті почала стрімко зменшуватися й у 2013 р. у світовому туристичному рейтингу Сгипет посів на 10 позицій нижче місце (опустившись із 75 на 85 позицію). Численна кількість терористичних атак і погроз не завершилася й у наступні роки, коли збито авіалайнер Airbus A321-231 над Синайським півостровом 31 жовтня 2015 р. і відбулись атаки в Хургаді у 2017 р. Як наслідок, у 2017-2018 pр. у Сгипті введено режим надзвичайного стану, що негативно позначилося на динаміці надходжень від туризму в країні (рис. 1).

Попри те, що динаміка туристських прибуттів до Єгипту з 2017 р. почала зростати, початок пандемії коронавірусної хвороби мав негативний вплив. Аби зазнати найменших утрат від пандемії коронавірусної хвороби, міжнародні поїдки до Єгипту станом на 2021 р. є дозволеними, проте потрібно дотримуватися вимог, що забезпечують в'їзд до країни, а саме: наявність негативного тесту ПЛР тривалістю до 72 годин; заповнена «форма декларації про стан здоров'я», наявність туристичного страхування, що передбачає повне покриття медичних витрат на COVID-19 та низка інших вимог [24].

Попри загрози політичного характеру й поширення пандемії коронавірусної хвороби, кількість охочих відвідати Єгипет постійно 


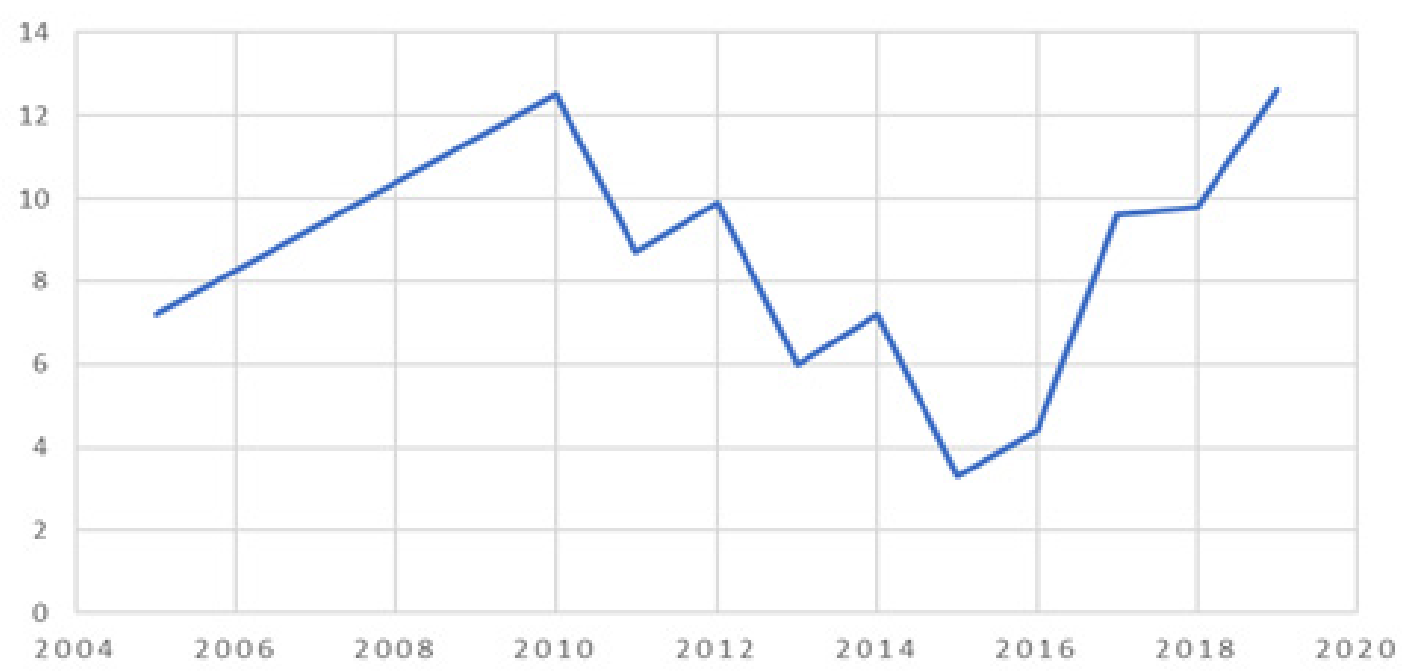

Рис. 1. Динаміка надходжень від туризму в Сгипті протягом 2005-2019 рр., млрд дол. США Складено за даними: [20].

зростає, адже сучасних туристів приваблюють пам'ятки давньоєгипетської, християнської (коптської) та середньовічної арабської цивілізацій, що представлені в ньому. Найпотужніші регіони-постачальники туристів до Сгипту представлено на рис. 2.

Найбільшою популярністю серед туристів користуються такі туристичні дестинації, як Абу Симбел, Александрія, Гіза з ії трьома великими пірамідами, а саме: Хеопса - єдиною вцілілою спорудою із переліку семи чудес давнього світу, Хефрена і Мікерина; Каїр із відомим

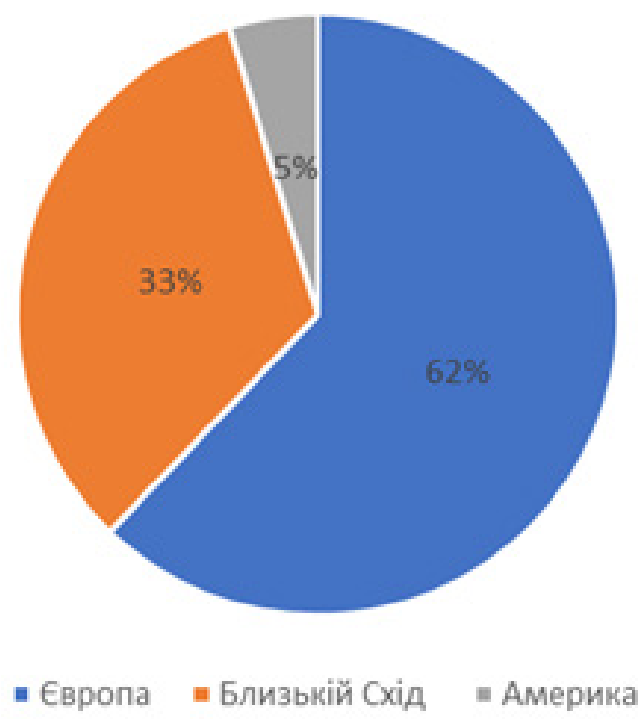

Рис. 2. Найбільші регіони-експортери туристів до Сгипту станом на 2019 р.

Складено за даними: [18]. 
на весь світ музеєм, де зберігається понад 150 тис. експонатів, розміщених у понад 100 залах; Луксор із усесвітньо відомими містами «мертвих» і «живих»; Хургада та Шарм Ель-Шейх, що приваблюють туристів купально-пляжним відпочинком; місця паломництва, серед яких гора Мойсея й монастир Святої Катерини та низка інших [16].

Цікавий той факт, що в Єгипті застосовують так званий «анклавний туризм», що має на увазі запровадження в практику системи «все включено» та обмеження впливу місцевого культурного й економічного середовищ, що, попри всі свої переваги, позбавляє туристів змоги відчути реальний культурний розвиток держави, побачити справжній рівень життя в Єгипті. За такою системою функціонують найбільші курорти Єгипту, якот Хургада, Шарм-ель-Шейх, Сафага, Марса-Алам та ін.

До найпоширеніших видів туризму, представлених у Єгипті на сучасному етапі, можемо віднести такі, як курортно-лікувальний, пляжний, культурно-розважальний, історико-культурний, пізнавально-діловий, релігійно-паломницький, екстремальний, спортивний, гастрономічний та iH.

Сприяє нарощенню туристського потенціалу Сгипту також той факт, що держава $\epsilon$ членом Всесвітньої туристичної організації, а на її території функціонують такі структурні одиниці останньої, як Туристична федерація Єгипту, основне завдання якої - сприяння розвитку туризму в державі; Асоціація готелів Сгипту й ін. [21].

\section{3. ВИСНОВКИ ТА ПЕРСПЕКТИВИ ПОДАЛЬШИХ ДОСЛІДЖЕНЬ}

Історія розвитку туризму в Єгипті досить тривала та складна; безпосередньо пов'язана 3 історією становлення тут державності. Загалом, можемо виділити три основні історичні етапи розвитку туризму в державі, a саме: 1) початковий, який охоплює IV ст. до н. е. - початок XX ст. і характеризується появою перших подорожей до Сгипту та 3 нього на основі торгових, пізнавальних, освітніх і військових мотивів; нарощенням культурно-пізнавального потенціалу держави; появою всесвітньо відомих культурно-історичних пам'яток держави; 2) етап зародження та еволюції організованого туризму (поч. XX ст. - кінець XX ст.), що характеризується організацією перших туристичних подорожей у повному сенсі цього поняття; появою й розвитком масового туризму; закладанням основ та еволюцією туристичної індустрії держави; активним ростом туристського потенціалу держави; 3) сучасний етап, що розпочався на початку XXI ст. і триває дотепер, саме під час цього історичного етапу, попри 
значну кількість політичних напружень у межах і поза межами держави, відбувся активний розвиток Сгипту як одного з найвідоміших туристичних центрів Африканського туристичного регіону. У подальших дослідженнях перспективним убачаємо вивчення характерних рис розвитку туризму Сгипту на сучасному етапі; аналіз проблемних питань із цієї тематики; здійснення SWOT-аналізу туристського потенціалу держави, на основі якого можливим стає обгрунтування перспектив та основних завдань розвитку туризму в ній.

\section{СПИСОК ВИКОРИСТАНИХ ДЖЕРЕЛ}

1. Бандурка, О. М. (2005). Історія держави і права зарубіжних країн: підручник. Харків: Майдан.

2. Абрамов, В. В., Тонкошкур, М. В. (2005). История туризма. Харків .: ХНАГХ.

3. Великочий, В. С., Дутчак, О. І., Шикеринець, В. В. (2015). Міжнародний туризм: навч. посіб. для студентів спец. 8.14010301 «Туризмознавство». ІваноФранківськ: Вид. Кушнір Г. М.

4. Путрик, Ю. С., Багдасарян В. Э., Биржаков М. Б. (2014). История туризма: учебник. Москва: Федеральное агентство по туризму.

5. Соколова, М. В. (2002). История туризма: учеб. пособие. Москва: Мастерство.

6. Martin, Anderson (2012). The development of British tourism in Egypt, 1815 to 1850. Journal of Tourism History, 4 (3), 259-279. DOI https://doi.org/10.1080/175518 2X.2012.711373

7. Mohamed, Negm. History of Tourism in Egypt from 2010-2017, Challenges and Future Opportunities. Internet resource: https://www.meobserver.org/?p=14733 (accessed on 30.04.2021).

8. Божидарник, Т. (2019). Міжнародний туризм. Київ: Центр навч. літ.

9. Мальська, М. П., Худо, В. В., Цибух В. І. (2004). Основи туристичного бізнесу: навч. посіб. Київ: Центр навч. літ.

10. Воронкова, Л. П. (2004). История туризма и гостеприимства. Москва: ФаирПреcc.

11. Воронкова, Л. П. (2001). История туризма: учеб. пособие. Воронеж: НПО «Модек».

12. Дулов, А. Н. (2011). История путешествий и туризма: монография. Витебск: УО «ВГУ им. П. М. Машерова».

13. Устименко, Л. М., Афанасьєв, І. Ю. (2005). Історія туризму: навч. посіб. Київ: Альтерпрес.

14. Дмитриевский, Ю. Д. (2000). Туристические регионы мира: учеб. пособие. Смоленск.

15. Мальська, М. П. (2008). Міжнародний туризм і сфера послуг: підручник. Київ: Знання.

16. Масляк, П. О. (2008). Рекреаційна географія: навч. посіб. Київ: Знання. 
17. Терещенко, В. І., Штанько, Л. О., Чаплигін В. П. (2019). Соціально-економічні основи рекреації та туризму: навч. посіб. Київ: Міленіум.

18. Puri-Mirza, Amna. Tourism industry in Egypt - statistics \& facts Internet resource: https://www.statista.com/topics/5767/tourism-industry-of-the-egypt/ (accessed on 30.04.2021).

19. Vignal, Leila (2010) The new territories of tourism in Egypt: a local-global frontier? Space, Society, Territory, 509-510. DOI https://doi.org/10.4000/cybergeo.23324 https://journals.openedition.org/cybergeo/23885

20. UNWTO Internetresource: https://www.unwto.org/search?keys=egypt (accessed on 30.04.2021).

21. Египет Интернет ресурс: https://travelife.today/afrika/egipet/\#h4-ofitsial-nyjyazyk (доступ 30.04.2021).

22. История Египта кратко: от древних богов до туризма. Интернет-ресурс: http://jj-tours.ru/articles/Egypt/egypt-istoria.html (доступ 30.04.2021).

23. Современный Египет. Интернет-ресурс: https://ru.egyptian.today/ (доступ 30.04.2021).

24. Сгипет: обмеження і подорожі. Інтернет-ресурс: https://www.skyscanner.com. ua/travel-restrictions/egypt/29475226 (доступ 30.04.2021).

\section{HISTORICAL STAGES OF TOURISM DEVELOPMENT IN EGYPT}

The article explored Egypt as one of the leading tourist destinations in the modern world. The necessity of research and analysis of the main stages of tourism formation in Egypt was studied and substantiated. The characteristic features of the state formation of Egypt were considered. It was proved how the history of statehood in Egypt influenced the peculiarities of the origin and evolution of tourism in it. The main works of domestic and foreign scientists on the analysis of tourism development and the formation of the tourism industry in the country were studied. Scientific methods were explained, the application of which allowed comprehensively to study and analyze the historical stages of tourism formation in the country. Based on the results of the study, the article proposed to identify 3 main stages of historical development of tourism in Egypt, namely: 1) the initial (IV c. BC-early XX c.), characterized by the appearance of the first trips to and from Egypt on the basis of trade, cognitive, educational and military motive; increasing of the cultural and cognitive potential of the state; the construction of famous cultural and historical monuments of the state; 2) the emergence and evolution of organized tourism (early XX c. - end of XX c.), characterized by the organization of the first tourist trips; laying the foundations for the 
development of the tourism industry; the emergence of mass tourism; increasing of the tourist potential of the state; 3 ) modern (early XXI c. - present times) - the active development of Egypt as one of the most famous tourist centers of the African tourist region. In the article, the main characteristics of each of the studied stages were revealed. The expediency of their allocation in such time frames, which were presented in the article, was substantiated. The main types of travel into and from Egypt until the beginning of the XXI century were analyzed, as well as the main types of tourism presented in the country at the present stage were studied. The article examines the political, legal, socio-economic and cultural factors of tourism development in the country at each of the proposed historical stages. The main characteristics of tourism development in Egypt at the present stage were considered and the main prospects of further research on the selected scientific topic were substantiated.

Key words: tourism, historical stage, Egypt, historical and cultural monument, evolution, travel.

\section{REFERENCES}

1. Bandurka, O. M. (2005). Istoriya derzhavy i prava zarubizhnykh krayin: pidruchnyk. [History of the state and law of foreign countries: a textbook]. Kharkiv: Maydan. (in Ukrainian).

2. Abramov, V. V., Tonkoshkur, M. V.(2005). Istoriya turizma. [History of tourism] Kharkiv: KHNAGKH (in Russian).

3. Velykochyy, V. S., Dutchak, O. I., Shykerynets', V. V. (2015). Mizhnarodnyy turyzm: navchal'nyy posibnyk dlya studentiv spetsial'nosti 8.14010301 «Turyzmoznavstvo». [International tourism: a textbook for students of speciality 8.14010301 «Tourism»]. Ivano-Frankivs'k: Vydavets' Kushnir H. M. (in Ukrainian).

4. Putrik, Y. S., Bagdasaryan V. E., Birzhakov M. B. (2014). Istoriya turizma. Uchebnik. [History of tourism. Textbook]. Moskva: Federal'noye agentstvo po turizmu (in Russian).

5. Sokolova, M. V. (2002). Istoriya turizma: Ucheb. posobiye [History of tourism: textbook]. Moskva: Masterstvo (in Russian).

6. Martin, Anderson (2012). The development of British tourism in Egypt, 1815 to 1850. Journal of Tourism History, 4 (3), 259-279. DOI https://doi.org/10.1080/175518 2X.2012.711373

7. Mohamed, Negm. History of Tourism in Egypt from 2010-2017, Challenges and Future Opportunities. Internet-resource: https://www.meobserver.org/?p=14733 (accessed on 30.04.2021).

8. Bozhydarnyk, T. (2019). Mizhnarodnyy turyzm. [International tourism]. Kyyiv: Tsentr navchal'noyi literatury (in Ukrainian). 
9. Mal's'ka, M. P., Khudo, V. V., Tsybukh V. I. (2004). Osnovy turystychnoho biznesu: navchal'nyy posibnyk. [Fundamentals of tourism business: a textbook]. Kyyiv: Tsentr navchal'noyi literatury (in Ukrainian).

10. Voronkova, L. P. (2004). Istoriya turizma i gostepriimstva. [History of tourism and hospitality]. Moskva: Fair-Press (in Russian).

11. Voronkova, L. P. (2001). Istoriya turizma: Uch. Posobiye. [Tourism history: Textbook]. Voronezh: NPO «Modek» (in Russian).

12. Dulov, A. N. (2011). Istoriya puteshestviy i turizma: monografiya. [The history of travel and tourism: monograph]. Vitebsk: UO «VGU im. P. M. Masherova» (in Russ.).

13. Ustymenko, L. M., Afanas'yev, I. YU. (2005). Istoriya turyzmu: navchal'nyy posibnyk. [History of tourism: a textbook]. Kyyiv: Al'terpres (in Ukrainian).

14. Dmitriyevskiy, YU. D. (2000). Turisticheskiye regiony mira: Uchebn. posobiye. [Tourist Regions of the World: textbook]. Smolensk (in Russian).

15. Mal's'ka, M. P. (2008). Mizhnarodnyy turyzm i sfera posluh: pidruchnyk. [International tourism and services: a textbook]. Kyyiv: Znannya (in Ukrainian).

16. Maslyak, P. O. (2008). Rekreatsiyna heohrafiya: Navchal'nyy posibnyk. [Recreational Geography: a textbook]. Kyyiv: Znannya (in Ukrainian).

17. Tereshchenko, V. I., Shtan'ko, L. O., Chaplyhin V. P. (2019). Sotsial'noekonomichni osnovy rekreatsiyi ta turyzmu: nav.pos. [Socio-economic bases of recreation and tourism: textbook]. Kyyiv: Milenium (in Ukrainian).

18. Puri-Mirza, Amna. Tourism industry in Egypt - statistics \& facts Internet resource: https://www.statista.com/topics/5767/tourism-industry-of-the-egypt/ (accessed on 30.04.2021).

19. Vignal, Leila (2010). The new territories of tourism in Egypt: a local-global frontier? Space, Society, Territory, 509-510 DOI https://doi.org/10.4000/cybergeo.23324 https://journals.openedition.org/cybergeo/23885

20. UNWTO Internet-resource: https:/www.unwto.org/search?keys=egypt (accessed on 30.04.2021).

21. Yegipet. Internet resurs [Egypt. Internet-resource]. https://travelife.today/afrika/ egipet/\#h4-ofitsial-nyj-yazyk (dostup 30.04.2021) (in Russian).

22. Istoriya Yegipta kratko: ot drevnikh bogov do turizma. Internet-resurs [The history of Egypt in brief: from ancient gods to tourism. Internet-resource]. http://jj-tours.ru/ articles/Egypt/egypt-istoria.html (dostup 30.04.2021) (in Russian).

23. Sovremennyy Yegipet. Internet-resurs [Modern Egypt. Internet-resource]. https:// ru.egyptian.today/ (dostup 30.04.2021) (in Russian).

24. Yehypet: obmezhennya i podorozhi. Internet-resurs [Egypt: restrictions and travel. Internet resource] https://www.skyscanner.com.ua/travel-restrictions/egypt/29475226 (dostup 30.04.2021) (in Ukrainian).

Матеріал надійшов до редакиії 06.01.2021 p. 